\title{
Drucker-Prager 型構成則を用いた \\ 円柱コンファインドコンクリート供試体の圧縮破壊 FEM 解析 \\ COMPRESSIVE FAILURE 3-D FEM ANALYSIS OF \\ CYLINDRICAL CONFINED CONCRETE WITH THE DRUCKER-PRAGER MODEL
}

\author{
吉田幸夫*1，畑中重光*2，水野英二*3 \\ Yukio YOSHIDA, Shigemitsu HATANAKA and Eiji MIZUNO
}

\begin{abstract}
Main purpose of the present study is to discuss the effect of parameters (e.g. internal friction angle and dilatancy angle) of the constitutive law of Drucker -Prager type on the result of simulation analysis of confined concrete under compression. Two series of 3-D FEM analyses have been carried out. Firstly, the optimum values of the internal friction angle and dilatancy angle, used in the Drucker-Prager type plasticity model with the strain softening effect, have been discussed for a set of compressive strength data of concrete specimens with different shapes. As a result, reasonable value as the internal friction angle has been found to be approximately 30 degrees for a condition of rather high equivalent lateral pressure. Secondly, simulation analyses have been carried out for the compressive behavior of cylindrical concrete specimens confined by steel tubes or reinforcing bars, introducing interface element and different values of the internal friction angle. As a result, it has been pointed out that the distribution of equivalent confining pressure along the longitudinal direction of a specimen and the progress of the degree of damage in horizontal sections differ to a large extent by the value of internal friction angle applied.
\end{abstract}

Keywords: 3-D FEM Analysis, Shape of Specimen, Failure Criterion of Drucker-Prager Type, Internal Friction Angle, Uniaxial Compression, Constitutive Law

三次元 FEM 解析，供試体形状，Drucker-Prager 型破壊基準，内部摩擦角，一軸圧縮，構成則

1. はじめに

筆者らは前報 1)で, コンクリートの構成則にひずみ軟化を考慮で きる Drucker-Prager 型構成則を導入した三次元有限要素解析プログ ラム DIANA ${ }^{4)}$ を用い，1) 圧縮力を受けるコンファインドコンクリ ートの解析に用いる Drucker-Prager 型構成則のパラメータ同定を行 うとともに，2）それらパラメータを用いた解析結果に基づいてコ ンファインドコンクリートの内部性状を議論した．その結果，1) 一定の均等な低側圧を受ける一要素のコンクリートの最適な内部摩

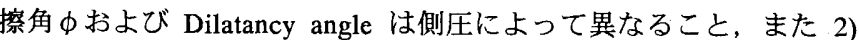
鋼管および帯筋により横拘束された円柱コンファインドコンクリー トの圧縮性状をシミュレーション解析する際には, 境界要素の導入 が有効であること，などを示した．ただし，前報1でも示したよう に，コンクリートに適用する破壊基準を Drucker-Prager 型とした場 合の内部摩擦角 $\phi$ の值は研究者によってかなりの差が見られる. 前 報 ${ }^{1)}$ では, ある限られた範囲の実験デー夕に対してこの值（ $\phi=$ $\left.53^{\circ}\right)$ を同定し，これを用いたシミュレーション解析を行っている
が，解析結果に及ぼす内部摩擦角 фの影響は必ずしも明らかになつ ていない.

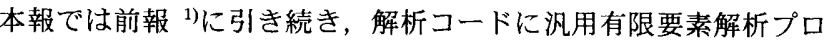

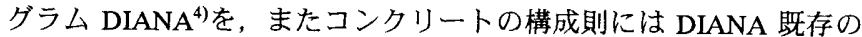
Drucker-Prager 型構成則を用い, 以下の 2 ケースについて解析を行 5 .

解析 I：形状比（供試体の高さ一直径比であり, 以下, H/D と称 する）が異なり，端面摩擦を有する円柱プレーンコンクリート供 試体の一軸圧縮 FEM 解析 ${ }^{3)}$ を通して, 最大圧縮応力の実験值を 再現する内部摩擦角 $\phi$ の值を求める.

解析 1I：円柱コンファインドコンクリートの圧縮破嘼解析 ${ }^{2)}$ 通して, 内部応力状態や損傷状態といった内部性状に及ぼす内部 摩擦角 $\phi$ の影響を調べる.

\section{Drucker-Prager 型構成則に関する既往の研究}

Drucker-Prager 型の破壊曲面の主応力空間での形状は円錐形とな

本報は，前報1の続報で，支献2）および3）に加筆・修正したものである

*1 三重大学大学院丁学研究科 大学院生・工修

*2 三重大学工学部建築学科 教授. 工博

*3 中部大学工学部都市建設工学科 教授・Ph. D.

Grad. Student, Grad. School of Eng., Faculty of Eng., Mie Univ., M. Eng. Prof., Dept. of Architecture, Faculty of Eng., Mie Univ., Dr. Eng. Prof., Dept. of Civil Eng., Faculty of Eng., Chubu Univ., Ph. D. 
つており，圧縮の静水圧軸に沿って円錐形の裾が大きくなる形状を 示す．また，その円錐形の勾配は内部摩擦角の值により決定される という特徴を持っている.

Drucker-Prager 型の破壊基準の利点として, パラメータが 2 つ 少なく，取り扱いが簡便であることが挙げられる．逆に欠点として， 例えば，一般のコンクリートの主応力空間における破壊曲面の経線 は, 圧縮の静水圧が増大することによりその勾配が緩やかになる (曲線になる) ことから, 静水圧の変動に伴う経線の公配を十分に 表示し得ず，実験結果を過大または過小に評価するという点が挙げ られる.

Drucker-Prager 型構成則とは，塑性論に基づき破壊曲面（負荷曲 面）の勾配および切片を変動させることでひずみ硬化および軟化挙 動を再現するモデルである 7) 12)．本モデルを適用した既往の解析 的研究では, 内部摩擦角の取り扱い方に 2 種類の方法がみられる. 一つは, コンクリートの内部性状の変化に応じて内部摩摖角を変化 させる方法，いま一つは，内部摩摖角を一定值とする方法である. 前者の一例として, Tanabe $5^{7}$ は, 内部摩擦角を最大 $30^{\circ}$ として コンクリートの損傷の程度に応じて角度を変化させる構成則を提案 し，コンファインドコンクリートの解析を行っている．また，

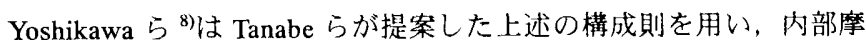
擦角の最大值を $20 \sim 45^{\circ}$ と設定して Tanabe らと同様な解析を行っ ている。, 一方, 後者の一例として, Karabinas ら ${ }^{9}$ は内部摩摖角を $30^{\circ}$ として鉄筋コンクリート部材の解析を行い, 山川ら ${ }^{(0) \sim 12)}$ は内 部摩擦角を $27^{\circ}$ として繊維シートを拘束材に適用したコンクリー ト部材の解析を行っている。このように，コンファインドコンクリ 一トの解析では, 内部摩摖角は $30^{\circ}$ 前後とする傾向がある. しか し，これらの值の根拠および適用範囲は必ずしも明確に示されては いない，また，石丸ら ${ }^{13)}$ は，無拘束のコンクリートにくさび理論 を適用した結果, 内部摩擦角を $50^{\circ}$ とすると実験結果にほほ一致 すると報告している，これらのことから Drucker-Prager 型構成則を 適用する際には，内部摩摖角の值を解析对象に応じて変化させるこ とが肝要であると考えられる.

\section{3. 解析 1（内部摩擦角の再検討）}

\section{1 解析目的}

図-1 は，端面摩擦が存在するという条件下での H/D の異なるコ
ンクリート供試体の最大圧縮応力を示したものである. ただし， H/D が 2 の供試体のそれで正規化してある ${ }^{14)}$.

本解析では, 内部摩擦角 $\phi$ および解析に用いる境界要素の剛性を パラメトリックに変化させることにより，図-1に示す既往の実験

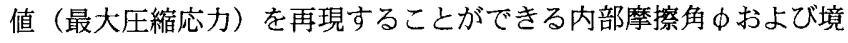
界要素の剛性について考察する.

\section{2 解析概要}

\section{2 .1 供試体および解析モデル概要}

图-2 に供試体概要を，表-1 に解析対象とした供試体シリーズを 示す。解析上のパラメー夕は, 内部摩摖角 $\phi$ おる゙境界要素の剛性 である. 解析対象部分は, 図-2(a)に示すように, 対称性を考慮し て供試体全体の $1 / 8$ とする. 端面摩擦を考慮するため, 同図(c)に示すように，コン クリート端面にすべりを考慮 できる境界要素を設定した。 厚さは $1 \mathrm{~mm}$ である.「厚さ $1 \mathrm{~mm} 」 と は ，$ 実際には境界 要素は存在しないことから, 本解析では極力薄くするとい う条件の下で設定している数 值である，境界要素の詳絒に ついては, 3.2.5 項で述べる。

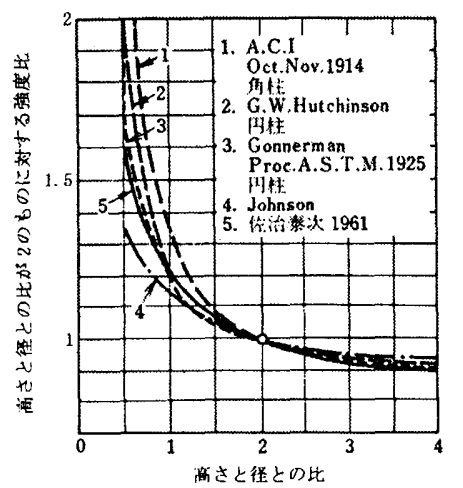

图-1 無次元化圧縮強度と H/D との 関係（文献 14）の図を一部修 正)

表-1 供試体シリーズ

\begin{tabular}{|c|c|c|c|}
\hline $\mathrm{H} / \mathrm{D}$ & 解析 & $\left.\phi=\psi()^{\circ}\right)$ & $D_{1}, \quad D_{2}$ \\
\hline$H(\mathrm{~mm})$ & & & $\left(\mathrm{N} /\left(\mathrm{mm}^{2} \times \mathrm{mm}\right)\right)$ \\
\hline 0.5 & 35 & \multirow{10}{*}{$\begin{array}{l}25 \\
30 \\
35 \\
40 \\
45 \\
50 \\
53\end{array}$} & \multirow{10}{*}{$\begin{array}{l}1.0 \times 10^{1} \\
1.0 \times 10^{2} \\
1.0 \times 10^{3} \\
1.0 \times 10^{4} \\
1.0 \times 10^{5}\end{array}$} \\
\hline 50 & & & \\
\hline 1 & \multirow{2}{*}{35} & & \\
\hline 100 & & & \\
\hline 1.5 & \multirow{2}{*}{35} & & \\
\hline 150 & & & \\
\hline 2 & \multirow{2}{*}{35} & & \\
\hline 200 & & & \\
\hline 3 & \multirow{2}{*}{35} & & \\
\hline 300 & & & \\
\hline
\end{tabular}

Dilatancy angle， $D_{1} ， D_{2}$ : 境界要素の剛性

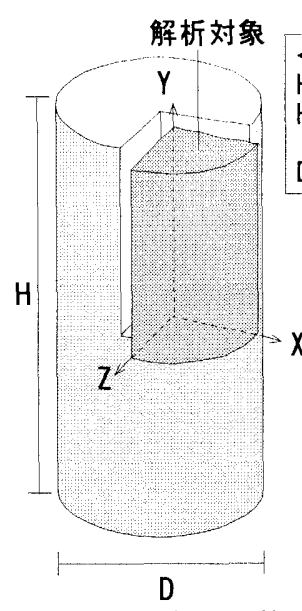

（a）供詰体の形状
〈供試体寸法〉

$H / D=0.5,1,1.5,2,3$ (コンクリート部分)

$H=50,100,150,200,300 \mathrm{~mm}$ (コンクリート部分) $+2 \mathrm{~mm}$ (境界要素部分)

$D=100 \mathrm{~mm}$

\section{$x$}

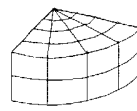

$H / D=0.5$

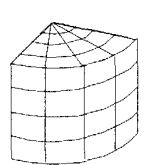

$H / D=1$

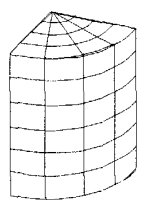

$H / D=1.5$

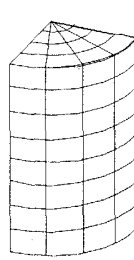

$H / D=2$

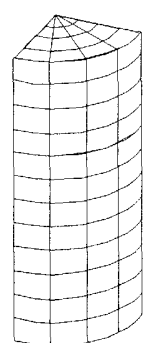

$H / D=3$ （b）メッシングの概要 図-2 供試体概要

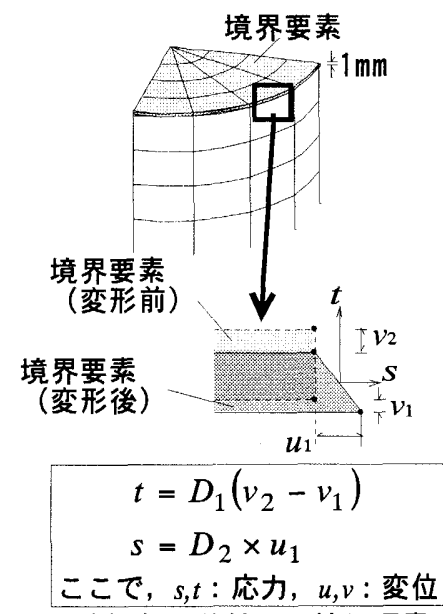

(c) 供試体端面の境界要素 
載荷方法は供試体上面に軸圧縮ひずみを与える変位制御とし, 1step 当たりの軸変位量を $4.0 \times 10^{-3} \mathrm{~mm}$ （例えば，供試体 $\mathrm{H} / \mathrm{D}=2$ で

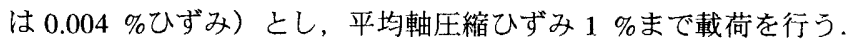
境界条件としては，対称面においては直角方向に変位を拘束した。 また，境界要素の上面である載荷面については，側方への変位，す なわち图-2(a)に示す $\mathrm{X}$ および $\mathrm{Z}$ 方向の変位を拘束した.

\section{2 .2 構成モデル，破壊基準および要素タイプ}

コンクリートの構成モデルとして, 前報 1)と同様, DIANA 既存 の Drucker-Prager 型構成則を, 破塄基準には同破壊基準を適用した 要素としては，20 節点アイソパラメトリック要素（DIANA での要 素名：CHX60）を採用した.

本研究で用いた DIANA 既存の Drucker-Prager 型構成則とは, 従 来のコーン状の破壊曲面と相似な曲面を負荷曲面として設定し, 引張側に位置する負荷曲面の頂点を静水圧軸に沿って移動させる （曲面を拡大および縮小させる）ことにより，ひずみ硬化および 軟化挙動を再現することができるモデルである．詳細は文献 15)を 参照されたい。

\subsection{3 材料定数}

表-2 にコンクリートの材料定数を示す。内部摩摖角 $\phi$ 抢よび Dilatancy angle $\psi$ は, 25 53ㅎ までの間で変化させ,ここでは, 関

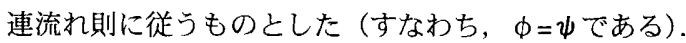

\subsection{4 コンクリートの軸圧縮応カ $\sigma$ ーひずみ $\varepsilon$ 関係}

三次元解析に採り入れるプレーンコンクリートの構成モデル (Drucker-Prager 型構成則) の一軸圧縮応力 $\sigma$ ーひずみ $\varepsilon$ 関係は,

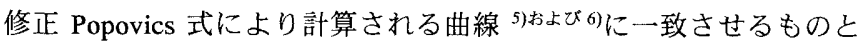
する. 式(1)に曲線式を示す.

$$
\begin{aligned}
& \text { (上昇域) } \eta=\frac{n_{a} \xi}{n_{a}-1+\xi^{n_{a}}} \\
& \text { (下降域) } \eta=\frac{1}{n_{d}}+\frac{\left(n_{d}-1\right) X}{n_{d}-1+X^{n_{d}}}
\end{aligned}
$$

ここで, $\eta=\sigma / F_{c}, \xi=\varepsilon / \varepsilon_{m}, \sigma$ : 応力, $F_{c}$ : 圧縮強度, $\varepsilon$ : ひずみ, $\varepsilon_{m}$ : 強度時ひずみ, $n_{a}=E_{c} /\left(E_{c}-F_{c} / \varepsilon_{m}\right), E_{c}$ : ヤング 倸数, $X=\xi^{m}, n_{d}=1+a\left(F_{c} / 10\right)^{b}, m, a, b:$ 定数（本研究で用い た値はそれぞれ $m=0.2, a=6, b=0.6)$ ，である.

この表示式による実測值の表示性能は，文献 5)および 6)によっ て示されている．図-3に，一軸圧縮応力 $\sigma$ ーひずみ $\varepsilon$ 関倸を示す。

プレーンコンクリートの一軸圧縮応力 $\sigma$ ーひずみ $\varepsilon$ 関係（ひずみ 軟化域を含む）を三軸状態での応力ーひずみ場に拡張するため， Drucker-Prager 型構成則のパラメー夕, すなわち, 粘着力 $c$ 一等価

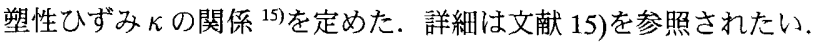

\section{2 .5 境界要素}

通常, 円柱コンクリートの一軸圧縮実験を行う場合, コンクリー 卜と載荷板とのポアソン比の違い，およびコンクリートと載荷板と の剛性の違いにより, 供試体端面は載荷板からの摩擦力を受ける 16). その現象を再現するため, 本解析では図-2（c）に示すようにコ ンクリート端面にすべりを考慮できる境界要素を設定した。

境界要素は，図一2（c）に示すように，材軸およびせん断方向（す ベり方向）の変位に応じて応力（同図中それぞれ $t$ および $s$ ）が算 定される要素モデルである，材軸およびせん断方向の剛性（それぞ
表-2 コンクリートの材料定数

\begin{tabular}{c|c|c|c|c|c}
\hline $\begin{array}{c}E_{c} \\
(\mathrm{MPa})\end{array}$ & $\nu_{c}$ & $\begin{array}{c}F_{c} \\
(\mathrm{MPa})\end{array}$ & $\begin{array}{c}F_{t} \\
(\mathrm{MPa})\end{array}$ & $\phi=\psi\left(^{\circ}\right)$ & $\begin{array}{c}G_{f} \\
(\mathrm{~N} / \mathrm{mm})\end{array}$ \\
\hline $2.6 \times 10^{4}$ & 0.2 & 30 & 2.4 & $\begin{array}{l}25,30,35,40, \\
45,50,53\end{array}$ & $9.7 \times 10^{-2}$ \\
\hline
\end{tabular}

[Notes] $E_{c}$ : ヤング係数, $\nu_{c}$ : ポアソン比, $F_{c}$ : 圧縮強度, $F_{t}:$ 引張強 度, $G_{f}:$ 引張破壊エネルギ
図-3 一軸圧縮応力 $\sigma$-ひずみ $\varepsilon$ 関係

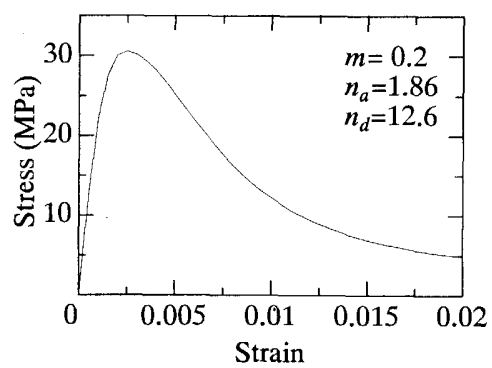

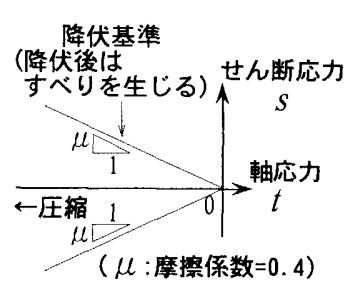

図-4 境界要素に適用し た降伏基準の概要
れ $D_{1}$ および $D_{2}$ ) は, 「単位面積当たり, それぞれ材軸方向および せん断方向の単位変位を生じさせるために必要な力」を意味する.

せん断方向の応力 $s$ については図-4 に示すように，その降伏值 が材軸方向の応力 $t$ に比例する．ここで, 同図の傾きとして与えら れる摩擦係数 $\mu$ の值は, 通常載荷時において $0.3 \sim 0.5$ 程度とされ ている例えば 16) 18)。本論文では，摩擦係数 $\mu$ の值を 0.4 と定めた。 なお, 降伏基準に達した後のせん断方向の剛性は, ゼロとする. 要素としては， $8+8$ 節点四辺形要素（要素名：CQ481）を採用した. ここで, 境界要素の材軸剛性 $D_{1}$ およびせん断剛性 $D_{2}$ を表-1に 示すように $1.0 \times 10^{1} \sim \times 10^{5} \mathrm{~N} /\left(\mathrm{mm}^{2} \times \mathrm{mm}\right)$ の間で変化させた. な お,ここでは $D_{1}=D_{2}$ とする.

\section{3 解析結果および考察}

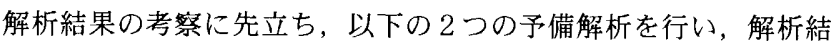
果への影響を確認している.すなわち，1）要素寸法が解析結果に 及ぼす影響を調べるため，図-2(b)に示した供試体 H/D = 1 および 2 について要素寸法を高さ方向に $1 / 2$ 倍（6.25 mm）および 2 倍 （25 mm）した場合の解析を実施した．解析結果によれば，この範 囲の差であれば，要素寸法の影響は，ほぼ無視できることを確認し ている，2）本解析供試体の境界要素には，図-4 に示すように，端 面摩擦を表現する手段としてすべりを考慮しているが，供試体端面 におけるせん断挙動を調べた結果, H/D = 1 以下の供試体では実際 にすべりが発生した．境界要素の構成モデルとして，例えばすべり を無視した弾性体を用いると，境界要素に生じるせん断応力が上述 のモデルを用いた場合より高くなり，供試体端面の拘束力が応力上 昇域で早期に大きくなるものと予想される。すなわち，得られる内 部摩擦角 $\phi$ は境界要素のモデルによって影響を受ける.内部摩擦角 $\phi$ を $30^{\circ}$ とし, 境界要素にすべりを無視した弾性体（剛性 $D_{1}$ 㧍よ び $D_{2}$ は後述の図-6 と同じ）のみを用いて解析した結果， $\mathrm{H} / \mathrm{D}=0.5$ および 1 では，最大圧縮応力がそれぞれ約 $17 \mathrm{MPa}$ および $0.3 \mathrm{MPa}$ だけ本解析結果より高くなり（同一の強度比を得るための内部摩擦 角 $\phi$ 值はそれに応じて小さくなる), 残りの H/D ではほぼ同一の 值となることを確認している.

\subsubsection{H/D-强度比関係}

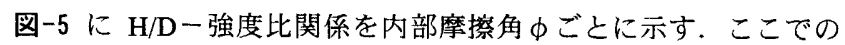
強度比とは, $\mathrm{H} / \mathrm{D}$ の異なる供試体の最大圧縮応力を, $\mathrm{H} / \mathrm{D}=2$ の端 面摩摖のある供試体の最大圧縮応力（ $F_{c}=33.2 \mathrm{MPa}$, 同図中に○と 


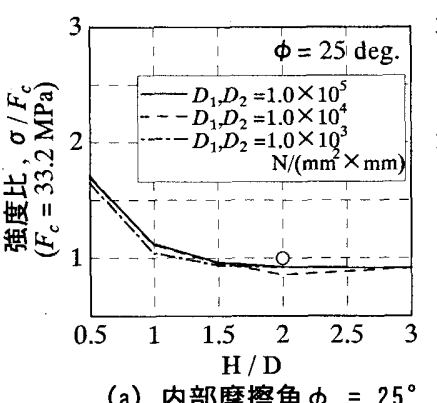

(a) 内部摩擦角 $\phi=25^{\circ}$

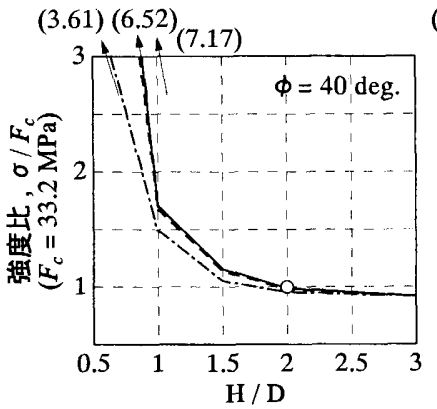

（d）内部摩撚角 $\phi=40^{\circ}$

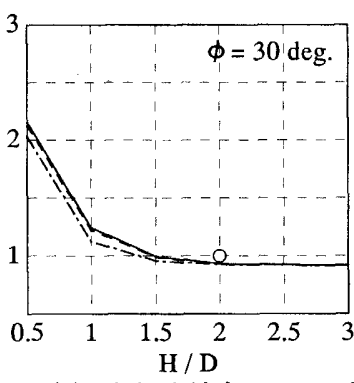

（b）内部摩擦角 $\phi=30^{\circ}$

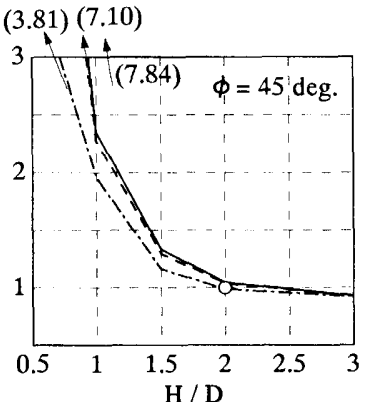

(e) 内部摩擦角 $\phi=45^{\circ}$

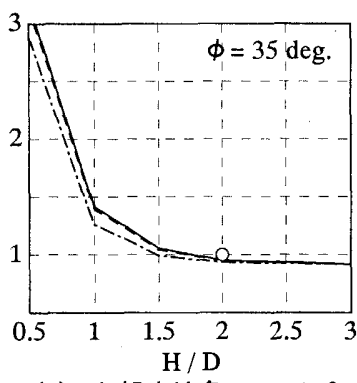

(c) 内部摩摖角 $\phi=35^{\circ}$

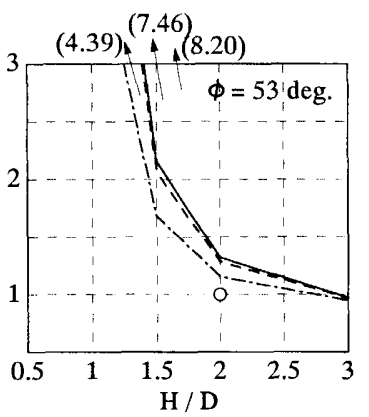

(f) 内部摩骤角 $\phi=53^{\circ}$ 5 の強度比を示している」

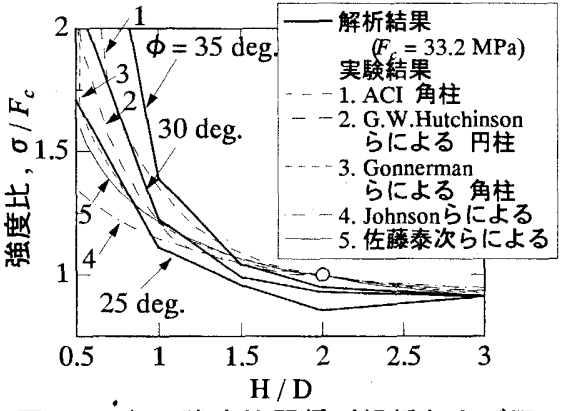

図-6 $\dot{H} / D$ - 强度比関係(解析および図-1 に示した実験結果 ${ }^{14)}$ の比較, 剛性 $\left.D_{1}=D_{2}=1.0 \times 10^{4} \mathrm{~N} /\left(\mathrm{mm}^{2} \times \mathrm{mm}\right)\right)$

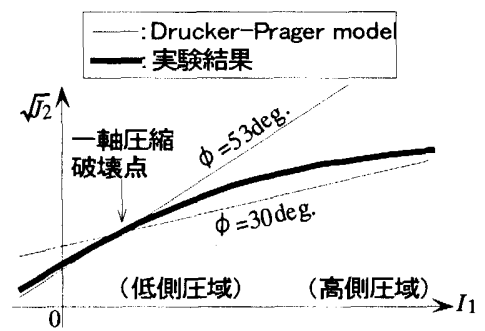

図-7 $I_{1}-\sqrt{J_{2}}$ 関係の概念図（圧縮子午線）
して表示している) で除したものである，H/D = 2 の最大生縮応力 $F_{c}=33.2 \mathrm{MPa}$ は, 文献 19)を参考にした. また, 同図には, 境界要 素の剛性が $1.0 \times 10^{3} \mathrm{~N} /\left(\mathrm{mm}^{2} \times \mathrm{mm}\right)$ 以上の結果のみを示してある. すなわち, 境界要素の剛性が $1.0 \times 10^{2} \mathrm{~N} /\left(\mathrm{mm}^{2} \times \mathrm{mm}\right)$ 以下では, 境界要素の剛性が低すぎることにより, どの解析結果も供試体全体 として非現実的な低い剛性となったため,ここでは, 考察の対象か ら除外した.

図-5より，H/D が 1.5 以下において，内部摩摖角 $\phi$ の影響が強度 比に顕著に現れている.すなわち，端面摩擦によって供試体に拘束

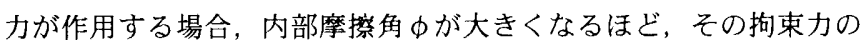
影響が大きく評価され，同図の結果になったものと思われる．なお， 内部摩擦角 $\phi 50^{\circ}$ の結果は, $\phi 53^{\circ}$ の結果に近いため割愛した.

図-6 は，図-1 に示した H/D の異なる供試体と最大圧縮灾力の関 係に関する実験結果, および内部摩摖角 $\phi$ が $25^{\circ} ， 30^{\circ}$ および $35^{\circ}$ における, 境界要素の剛性を $1.0 \times 10^{4}\left(\mathrm{~N} /\left(\mathrm{mm}^{2} \times \mathrm{mm}\right)\right)$ とした 時の解析結果を併示したものである. 同図より, 内部摩摖角 $30^{\circ}$ とすることにより, 図-1 に示した既往の実験結果とほぼ一致 することが分かる. ちなみに, 文献 7)〜12)で示されている内部摩 擦角 $\phi$ は $30^{\circ}$ 前後である.

\section{3. $3.2 I_{1}-\sqrt{J_{2}}$ 関係}

図-7 は，圧縮子午線における Drucker-Prager 型破壊基準と実際の コンクリートの破壊強度とを概念的に示したものである．低側圧域 の実験デー夕の表示性能を高めるには内部摩擦角 $\phi$ の值を大きく, 逆に高側圧域を再現するには内部摩擦角 $\phi$ 值を小さく設定すれば 良いことが分かる.ただし, 内部摩擦角 $\phi$ の值を小さく設定した場 合には，特に引張応力における上限強度の設定，いわゆる Tension Cut-off に注意する必要がある.ちなみに, Tension Cut-off を要しな い内部摩擦角 $\phi$ の值は約 $60^{\circ}$ である.

図-8 は, 圧縮子午線における Drucker-Prager 型破壊基準と文献 20)に示されている実験結果との比較を示したものである. 圧縮子
午線上での議論に限定 すると, 供試体内部に 生じる応力状態が低側 圧であれば，内部摩擦 角 $\phi$ を比較的高い值 （例えば $53^{\circ}$ ）上し， 一方, 高側圧では内部 摩摖角 $\phi$ を比較的低い 值 $\left(\phi 30^{\circ} \sim 40^{\circ}\right)$ と することで実験結果を

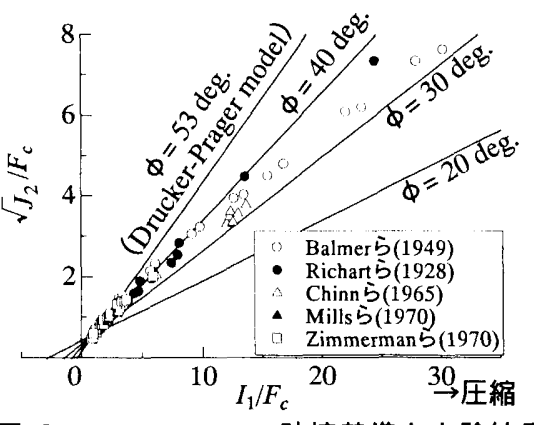

図-8 Drucker-Prager 破壊基準と実験結果 20) との比較（圧縮子午線）
精度良く評価することができる，ちなみに解析 Iの場合，ガウス積 分点に抢ける応力状態を調べたところ, 例えば, $\mathrm{H} / \mathrm{D}=0.5$ の供試 体内部では, $I_{1} / F_{c}$ の値は最大で約 4 であった.

また，実際のコンクリートの破壊は，必ずしも圧縮子午線上で生 じるわけではない，偏差断面が円である Drucker-Prager 型破壊基準 を適用する際の限界の一つとも言える. ただし本解析結果では，す べての供試体中の応力状態は, 最大応力時点で圧縮子午線側（ロー デ角が $35^{\circ} \sim 60^{\circ}$ の圧縮側) に位置しており, 引張子午線側の応 力状態は生じていない. ちなみに, 多くの実験結果の引張子午線は, 内部摩擦角 $\phi 20^{\circ}$ 前後であることを確認している.

\section{4. 解析 II（円柱コンファインドコンクリート供試体の解析）}

\section{1 解析目的}

解析 II では, 前報 ${ }^{1)}$ 之同様の円柱コンファインドコンクリート供 試体（図-9(b)の 6 供試体）について, 三次元圧縮破壊解析の結果 に及ぼす内部摩擦角 $\phi$ の影響を調べる，すなわち，異なる内部摩擦 角 值 $30^{\circ} ）$ を設定した場合について,

1) 供試体全体としての応力ーひずみ関係への影響を調べる.

2) 横拘束効果および破壊メカニズムについて，それぞれ等価拘束 


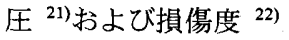
という 2 つの指標を 用いて考察する.

\section{2 解析概要}

4.2.1 供試体および解 析モデル概要

供試体の概要を図-9 に示す．供試体の形状は 円柱形（直径 $100 \mathrm{~mm} \times$ 高さ $100 \mathrm{~mm}$ ) とし, 対 称性を考慮して，全体の 1/8 の部分をモデル化 した. 境界条件は，対称 面においては直角方向に 変位を拘束し, 載荷面に おける横拘束はないもの とした．横拘束鋼材とコ ンクリートの間には境界 要素を設けた．載荷方法 は，供試体上面に $4.0 \times$ $10^{-3} \mathrm{~mm}(0.008 \%$ ひず み）の軸圧縮ひずみを与 える変位制御とし， $2 \%$ の平均軸圧縮ひずみまで 載荷を行った。供試体 S-1 のコンクリート充填 鋼管柱を想定した解析で は，コンクリート部分の みに強制変位を与える，

図-9(b)には，併せてメ ッシングの様子も示した.

\subsection{2 構成モデル，破壊基準および要素タイプ概要}

コンクリート部分の構成モデル，破壊基準および要素タイプは, 3.2 .2 項と同様とする. ちなみに, 筆者のこれまでの DIANA を用 いた解析的研究から, 以下の点が分かっている.すなわち, 1 次要 素を用いた同様の横拘束が離散的に作用する供試体の解析を行う場 合, 鋼材が降伏する時点（コンクリート要素に適用した内部摩擦角 $\phi か ゙ ~ 30^{\circ}$ および $53^{\circ}$ である供試体で，それぞれ概ね最大圧縮応力 時点近傍であった）において，解析計算が収斂しない。よって，1 次要素は取扱わないこととした。 なお， 1 次要素および 2 次要素を それぞれ用いた上記と同様の供試体のシミュレーション結果から, 平均軸圧縮応力 $\sigma$ ひずみ $\varepsilon$ 関倸および後述の等価拘束圧分布が, 最大圧縮応力時までほぼ等しいことを確認している。

鋼材は完全弾塑性体とし, 要素は図-9に示す供試体のタイプに より,一様および帯状に巻いた鋼管については Shell 要素（要素 名 : CQ40S）を，線材として巻いた帯筋には Beam 要素（要素名： CL9BE）を採用した.

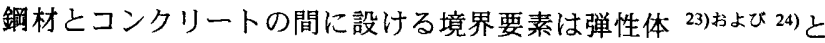
し, 要素としては鋼材が Shell 要素の場合は面要素（要素名 : CQ48I）を，Beam 要素の場合は線要素（要素名：CL12I）を採用し
コンクリート

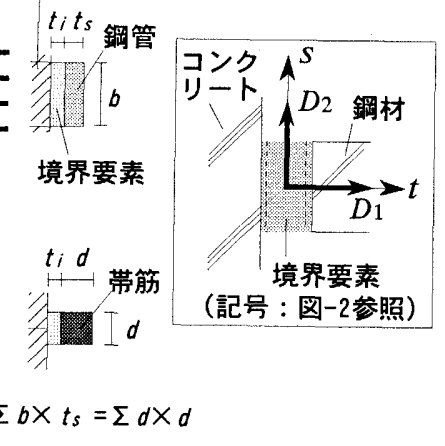

(c) 境界要素周辺の詳細

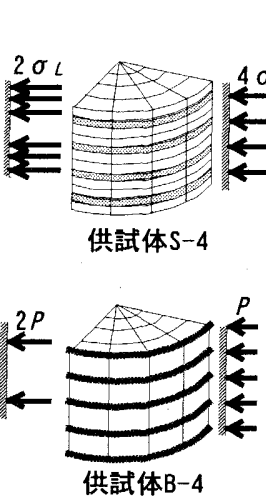

および Beam 要素を示す)

\begin{tabular}{|c|c|c|c|c|c|c|c|}
\hline \multicolumn{5}{|c|}{ コンクリート } & \multicolumn{3}{|c|}{ 鋼材 } \\
\hline$E_{\mathrm{c}}$ & $\nu_{c}$ & $F_{c}$ & $F_{t}$ & $\phi=\psi$ & $E_{s}$ & $\nu_{s}$ & $\sigma_{s y}$ \\
\hline 26 & 0.2 & 30 & 2.4 & 30,53 & 210 & 0.3 & 297 \\
\hline
\end{tabular}

表-4 各供試体の鋼材および境界要素の種類・寸法

\begin{tabular}{|c|c|c|c|c|c|c|c|}
\hline \multirow{2}{*}{\multicolumn{2}{|c|}{$\frac{\text { 供試体 }}{\text { 鎆材要素 }}$}} & $S-1$ & $S-2$ & $S-4$ & B-1 & B-2 & B-4 \\
\hline & & \multicolumn{3}{|c|}{ Shell 要素 } & \multicolumn{3}{|c|}{ Beam 要素 } \\
\hline \multicolumn{2}{|c|}{ 境界要素 } & \multicolumn{3}{|c|}{ 面要素 } & \multicolumn{3}{|c|}{ 線要素 } \\
\hline$t_{s}$ & \multirow[b]{2}{*}{$d$} & 0.28 & 0.56 & 1.12 & \multirow{2}{*}{3.74} & \multirow{2}{*}{2.65} & \multirow{2}{*}{1.87} \\
\hline$b$ & & 50 & 12.5 & 3.13 & & & \\
\hline \multicolumn{2}{|c|}{$s$} & - & $D / 4$ & $D / 8$ & $D / 2$ & $D / 4$ & $D / 8$ \\
\hline \multirow{2}{*}{\multicolumn{2}{|c|}{$t_{i}$}} & \multicolumn{3}{|c|}{$t_{s} / 200$} & \multicolumn{3}{|c|}{$d / 200$} \\
\hline & & 0.001 & 0.003 & 0.006 & 0.02 & 0.01 & 0.01 \\
\hline \multicolumn{2}{|c|}{$\rho_{s}$} & \multicolumn{6}{|c|}{0.56} \\
\hline \multicolumn{2}{|c|}{$\sigma_{L r}$} & \multicolumn{6}{|c|}{1.67} \\
\hline
\end{tabular}

管の厚さ $(\mathrm{mm}), b:$ 銅管の幅 $(\mathrm{mm}), d:$ 帯筋の断

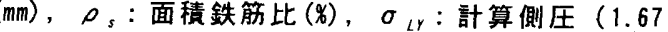
$\mathrm{MPa}) \sigma_{l y}=\rho_{s} \cdot \sigma_{s y}(\mathrm{MPa}), D$ : 供試体直径 $100 \mathrm{~mm}$

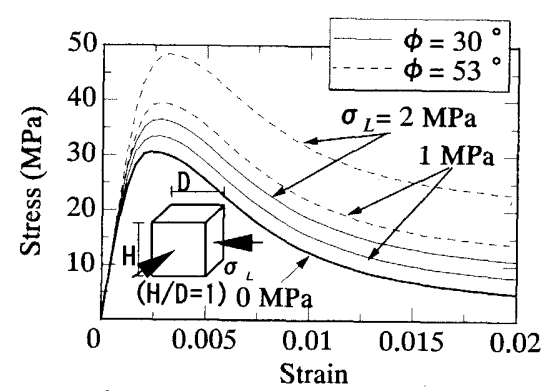

図-10 プレーンコンクリートの三軸圧縮下での 平均軸応力 $\sigma$ ーひずみ $\varepsilon$ 曲線 $(H / D=1)$

\begin{tabular}{c||c|c}
\multicolumn{2}{r}{ 表-5 解析 II ゙の境界要素の剛性 } \\
\hline 供試体 & $D_{1} t_{i} / E_{c}, D_{2} t_{i} / G_{c}$ \\
\cline { 2 - 3 } & $\phi=53^{\circ}$ & $\phi=30^{\circ}$ \\
\hline \hline$S-1$ & & \\
\hline$S-2$ & $1.0 \times 10^{-6}$ & $1.0 \times 10^{-3}$ \\
\hline$S-4$ & & \\
\hline B-1 & $6.7 \times 10^{-6}$ & $1.0 \times 10^{-4}$ \\
\hline B-2 & $5.0 \times 10^{-6}$ & $1.0 \times 10^{-3}$ \\
\hline B-4 & $4.0 \times 10^{-6}$ & $1.0 \times 10^{-3}$ \\
\hline
\end{tabular}

[Notes] $D_{1}, D_{2}$ : 境界要素の剛性, $t_{i}:$ 境界 要素の厚さ（図 $-9(c)$ 参照)， $G_{c}$ : コンクリートのせん断弾性係数

た ${ }^{1}$. また, 横拘束鋼材に Shell 要素（鋼管）を用いる場合, コン クリートと鋼管の節点間に Tying は設けないこととした ${ }^{1)}$. Tying とは, 鋼材近傍のコンクリートの節点変位とその鋼材の節点変位を 同一とする操作である.

\subsection{3 材料定数}

コンクリートと鋼材の材料定数には，表-3に示す值を用いる.

解析 II で用いるプレーンコンクリート（側圧 $\sigma_{L}=0 \mathrm{MPa} ）$ の平 均軸応力 $\sigma$ ーひずみ $\varepsilon$ 曲線を図-10 に示す. 図中には, 側圧（ $\sigma$ $L$ ）を作用させた場合の平均軸応力 $\sigma$-ひずみ $\varepsilon$ 関係の計算値も示 してある.

表-4に，各供試体の鋼材および境界要素の種類・寸法を示す. 各供試体の鋼材量が一定となるよう，面積鉄筋比 $\rho_{s}$ を一定とし， 横拘束方法を 6 種類（図-9(b)に示す 6 供試体）に変化させた.こ のときの計算側圧は $1.67 \mathrm{MPa}$ であり, 全供試体について一定であ る.

境界要素の厚さが鋼材に対して $1 / 200$ と非常に薄い理由は, 厚さ 自体が解析結果に影響を与えないように極力薄くするためである.

既報 ${ }^{24)}$ によれば，境界要素の剛性によって，鋼材からの拘束力 の作用の程度が大きく異なるので，ここでは，境界要素の剛性を以 
下のように決定した.

1) 鋼管で横拘束した供試体 S-1 の最大圧縮応力時点で, 鋼管が降 伏するように境界要素の剛性を定め, それを供試体 S-2 および S-4 に適用する.

2) 帯筋で横拘束した供試体 B-1〜B-4 の圧縮強度の解析值を, H / D が 2 であるコンファインドコンクリート供試体に対する既 往の評価式 ${ }^{25)}$ で求めた最大圧縮応力に一致するように境界要素 の剛性を定める．なお，このときの評価式 ${ }^{25}$ による圧縮強度は， 供試体ごとに, B-1 : 32.8, B-2 : 35.1, B-4 : 36.2 (MPa)である. 表-4 のパラメー夕值を用いて予備解析を行い, その結果に基づ いて定めた各供試体の境界要素の剛性を表-5 に示す．なお，同

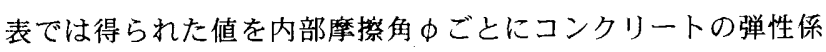
数 $\left(E_{c}, G_{c}\right)$ に対する比 $\left(D_{1} t_{i} / E_{c}, D_{2} t_{i} / G_{c}\right)$ として示して ある. 同表の值によれば, コンファインドコンクリートの最大 圧縮応力を再現するという条件で求めた境界要素の剛性は，コ ンクリートの内部摩摖角 $\phi$ がさくなると高い值を設定しなく てはならないことが分かる.

\section{3 解析結果と考察}

ここで予備解析として以下の 2 点を行い, 解析結果への影響を確 認している。すすなわち，1）供試体 B-2 の带筋（Beam 要素）を鋼管 (Shell 要素) に置き換え，他の解析パラメー夕は同一として平均 軸圧縮応力ーひずみ関倸を調べた，その結果, 要素の違いによる平 均軸圧縮応力ーひずみ関係の差は，ほぼ無いことを確認している.

2) 要素寸法の依存性を調べるため, 図-9に示す全供試体の要素寸 法を高さ方向に $1 / 2$ 倍した，すなわち，要素数を 2 倍とした供試体 について要素寸法の低存性を調べた，その結果，要素寸法の影響は ほぼ無視できることを確認している.これは, 以下の理由による. すなわち, 全ての供試体の全載荷ステップにおいて, 供試体内部の 応力状態が圧縮応力場であり（压縮子午線側に位置している）, 䫓 著な破壊の集中が起こらなかったことによるものと思われる.

等価拘束压 $\sigma_{c}$ 㧍よび損傷度 $\beta$ の分布・進展に関する考察を 4.3.3 項以降で行うが, それに先立ち, 以下に等価拘束圧 $\sigma_{c}$ 拉よ び損傷度 $\beta$ について簡単に説明する。

\subsection{1 等価拘束圧 $\sigma_{c}$ および損傷度 $\beta$ の定義}

等価拘束圧 $\sigma_{c}{ }_{c}^{21)}$ は, 一般忍力状態を三軸主応力状態に変換した 時の拘束圧のことである. 図-11 にその概要図を示す．ここでの三 軸主応力状態とは, 三軸方向に拘束圧が作用した状態で一軸方向に のみ圧縮力を作用させた応力状態である、「等価」の意味は, この 三軸主応力の状態が一般応力状態と等価であるとしたことによる.

損傷度 $\beta^{22)}$ とは, 本報では, 主にひずみ軟化域での挙動を対象と するため, 破壊曲面からの低下の度合いとして以下のように定義し た. 図-12 に概要図を，式 (2) に損傷度 $\beta$ の定義式を示す.

$$
\beta=\frac{\sqrt{J_{2 f A}}-\sqrt{J_{2 A}}}{\sqrt{J_{2 f A}}}
$$

ここに, $J_{2 \mathrm{~A}}$ : ある要素の応力状態である同図A点から求められ る偏差応力の二次不変量 $J_{2}, J_{2 f A}$ : そのときの応力の一次不変量 $I_{1 \mathrm{~A}}$ から導き出される破壊時の偏差応力の二次不変量 $J_{2}$ である. つま り, 破壊曲面上では $\beta=0.0$, 静水圧軸 $I_{1}$ 上では $\beta=1.0$ となる. 同 因破線は損傷度 $\beta$ の值に対する応力状態を示している.
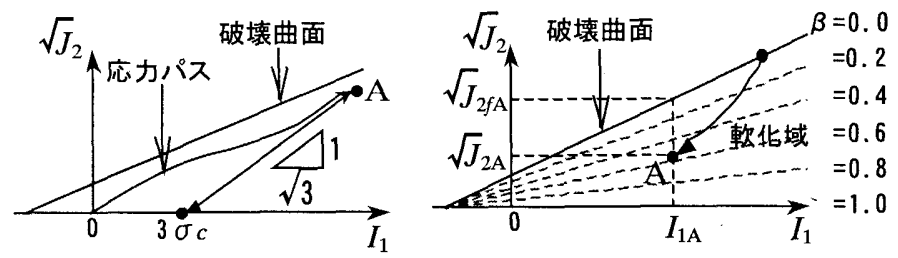

図-11 等価拘束圧 $\sigma_{c}$ の概要図 図-12 損傷度 $\beta$ (軟化域) の概要図

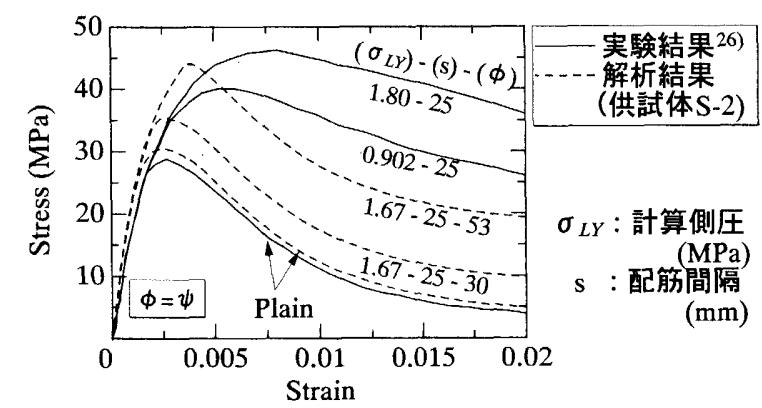

図-13平均軸応力 $\sigma$ ーひずみ $\varepsilon$ 関係（供試体 S-2 および文献 26))

\subsection{2 平均軸圧縮応力ーひずみ関係}

図-13 は, 供試体 S-2 の解析結果および文献 26)の実験による円 柱コンファインドコンクリート供試体の平均軸応力 $\sigma$-ひずみ $\varepsilon$ 関 倸を比較したものである. 同図の破線の Plain とは, 解析でコンク リート要素に適用した応力 $\sigma$ ーひずみを関倸を示している.

同図中の最大压縮応力に着目すると, 内部摩摖角 $\phi$ を $53^{\circ}$ とし た場合，計算側圧 $\sigma_{L Y}$ は若干異なるものの，解析結果は実験結果 （計算側圧 $\sigma_{L Y}=1.80 \mathrm{MPa}$ ，面積鉄筋比 $\rho_{s}=0.64 \%$ ）をほぼ再現し ているといえる. 一方, 内部摩摖角 $\phi$ を $30^{\circ}$ とした場合には最大 王縮応力を過小評価している，すなわち，低側圧下で最大圧縮応力 の実験值を再現するには, 内部摩摖角 $\phi$ は $53^{\circ}$ 程度が望ましい. また, 軟化域については, どの解析結果も実験結果ほどの延性的な 挙動を再現できていない。これは，既に文献 1)で指摘しているよ うに, Drucker-Prager 型構成則では経線が直線となっているためで あり，軟化域における実験結果を再現するには，側圧に応じて Dilatancy angle $\psi$ を変化させるなどの措置を施す必要がある ${ }^{1)}$.

\subsection{3 等価拘束圧 $\sigma_{c}$ および損傷度 $\beta$}

\section{(1) 等価拘束压 $\sigma_{c}$ の分布}

図-14 および図-15に，それぞれ供試体 S-2 および供試体 B-2 の $\mathrm{X}-\mathrm{Y}$ 面における, 等価拘束圧 $\sigma_{c}$ の高さ方向の分布を示す. 凡例中 の $\varepsilon_{p}$ とは，最大圧縮応力時の軸ひずみのことである．付図の $\mathrm{r}$ は 半径方向の距離を示し, 各プロットは $\mathrm{r}=50 \mathrm{~mm}$ では外周の節点で の值を，それ以外は近傍に位置するガウス積分点での值を表す。ま た，本解析条件として，すべての供試体の計算側圧 $\sigma_{L Y}$ を一定とし ていることから, 以下の考察において, 鋼材の降伏後の等価拘束圧 $\sigma_{c}$ の平均值はほぼ一定（同図の横軸の值が 1) となることに注意 されたい.

図-14によると, 同図 (a)では最大圧縮応力以後, 同図 (b)では全 ひずみレベルに㧍いて, 鋼管位置ではなく, その近傍のガウス積分 点での等価拘束圧 $\sigma_{c}$ が増大する傾向にある．これは，コンクリー 卜要素に 1 次要素 (解析コードには FEAP ${ }^{271}$ ) を用いている文献 24)でも指摘されているように，鋼管近傍の横拘束されていないコ ンクリート要素が側方へ変位するのを鋼管が抑制する，すなわち, 
鋼管から特に強い横拘束を受けるためで ある. 平均軸ひずみ $\varepsilon=1 \%$ 時点におけ る水平断面内のガウス積分点での違いを 示した同図(c)によれば，半径方向にお ける等価拘束圧 $\sigma_{c}$ の分布の一様性が大 きく崩れ，外周（r=50 mm）においては 同図 (b) と同様に拘束されていない筒所 の等価拘束压 $\sigma_{c}$ が高くなっている。こ れらの傾向は，図-15 でもほぼ同様に見 られる.

なお，図-14および-15 中には示して いないが, 内部摩擦角 $\phi 53^{\circ}$ の平均軸ひ ずみ $\varepsilon=1 \%$ 時点における等価拘束圧 $\sigma_{c}$ の分布は, 内部摩擦角 $\phi 30^{\circ}$ の結果

（図-14(c)および図-15(c)）と同様な傾 向を示すものの, 同図ほどの顕著な分布 は示さない。これは, 内部摩擦角 $\phi 53^{\circ}$ では $\phi 30^{\circ}$ に比べ，拘束位置とその近傍 の変位差（半径方向）が小さく, 従って 文献 24)に示されているような, 帯筋が 近傍の要素の側方への変位を拘束するこ とによって生ずる拘束力が内部摩摖角 $\phi$ $30^{\circ}$ ほどは強く作用しなかったことが原 因之考えられる。

ここで, 図-15 に示されているように 帯筋間の中央に位置するガウス積分点に も大きな等価拘束応力 $\sigma_{c}$ が発生してい る. 等価拘束圧という指標を用いた場合, このような分布状況が本解析条件下（2 次要素を用いていることなど) で見られ たものの, 図中には示していないが, 付 図の最外縁近傍（ $\mathrm{r}=48.6 \mathrm{~mm}$ ）に位置す るガウス積分点での $\mathrm{X}$ 軸方向の応力 （側方応力）の分布および進展状況を調 ベた結果, 側方応力は帯筋近傍のガウス 積分点で常に高く，帯筋間のガウス積分 点では低いことが分かった。

\section{（2）損傷度 $\beta$ の進展}

図-16 は，供試体 S-2 および B-2 につ いて，横拘束されている水平断面，すな わち, 下から $\mathrm{Y}=12.5 \mathrm{~mm}$ の位置での切 断面における，過去に経験した最大の損 傷度 $\beta$ の分布および進展を示したもので ある.

図-16(a)および (b) は，それぞれ内部 摩擦角 $\phi 53^{\circ}$ および $30^{\circ}$ をコンクリー トの構成則に適用し，鋼材要素を Shell 要素とした供試体 S-2 の結果である.両. 者の損傷度 $\beta$ の進展状況を見ると，損傷 度 $\beta$ の分布自体は類似しているといえる。

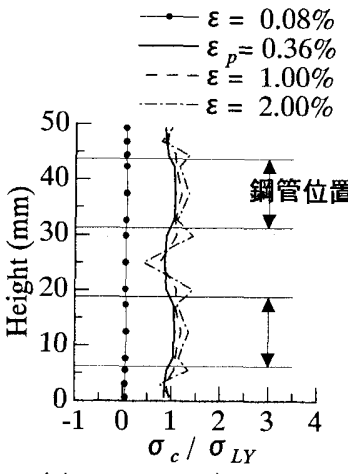

(a) $\left.\phi=53^{\circ} 1\right)(r=48.6)$

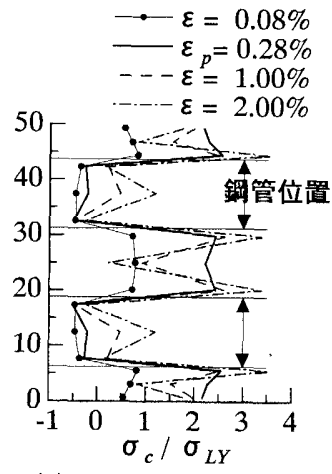

(b) $\phi=30^{\circ} \quad(r=48.6)$
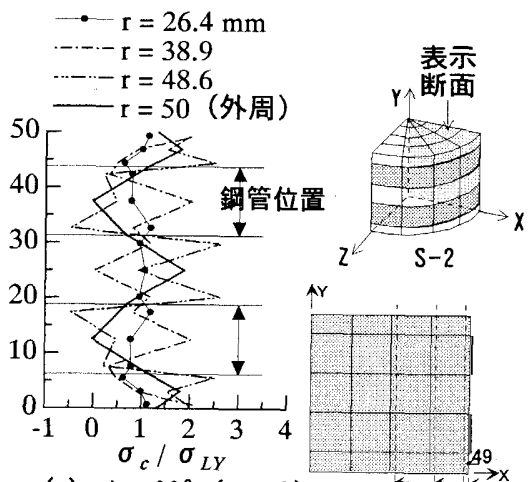

(c) $\phi=30^{\circ} \quad(\varepsilon=1 \%)$

$r=2639 \cdot 50 \mathrm{~mm}$

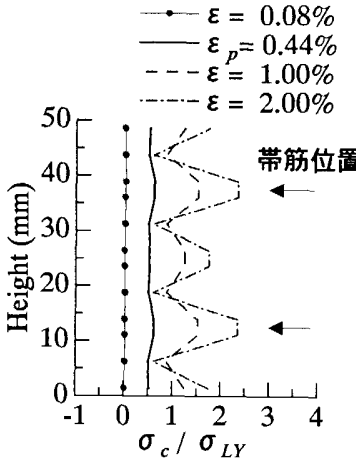

(a) $\left.\phi=53^{\circ} 1\right)(r=48.6)$

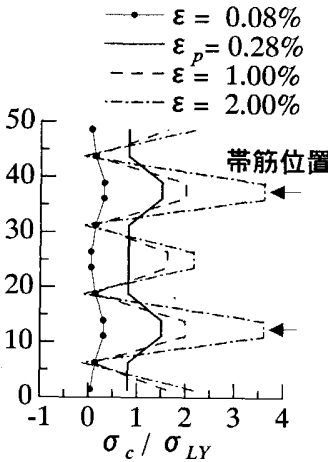

(b) $\phi=30^{\circ} \quad(r=48.6)$

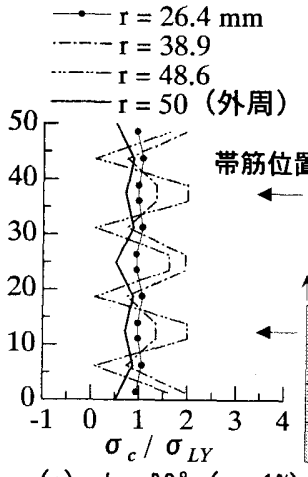

(c) $\phi=30^{\circ} \quad(\varepsilon=1 \%)$

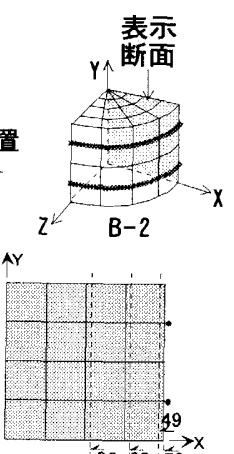

$r=2639 . \underset{50}{\longrightarrow} \mathrm{mm}$

图-15 X-Y 面における等価拘束圧 $\sigma_{c}$ の分布（供試体 B-2, 鋼材: Beam 要素, $\sigma_{l r}=1.67 \mathrm{MPa}$ )
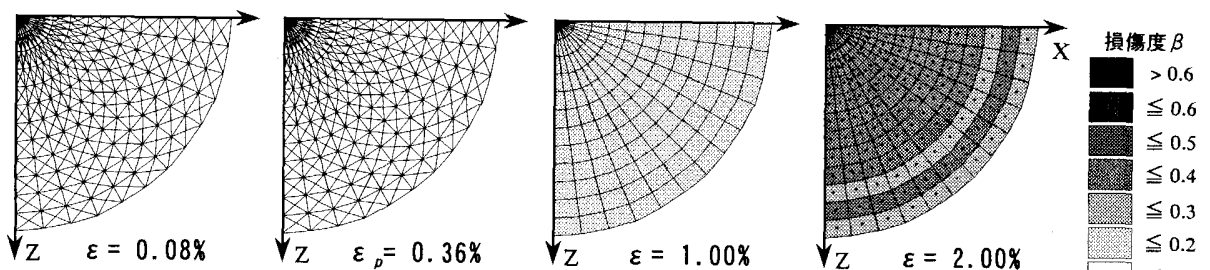

（a）供試体 S-2（龬材：Shell 要素, 内部摩擦角 $\phi 53^{\circ}$ ）1)
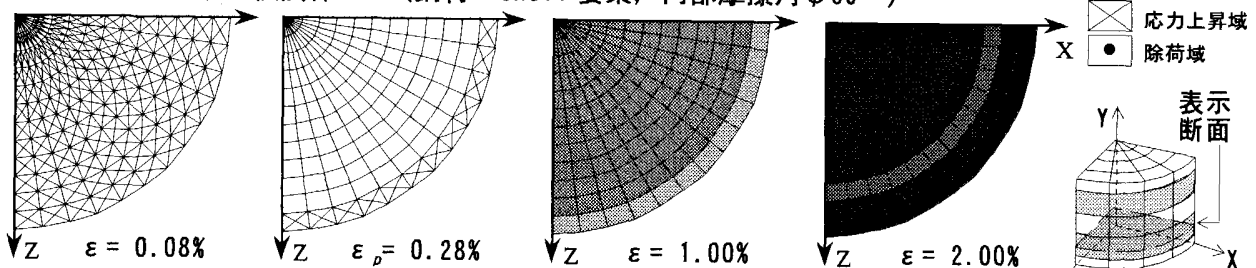

（b）供試体 S-2（鋼材：Shell 要素, 内部摩擦角 $\phi 30^{\circ}$ ）
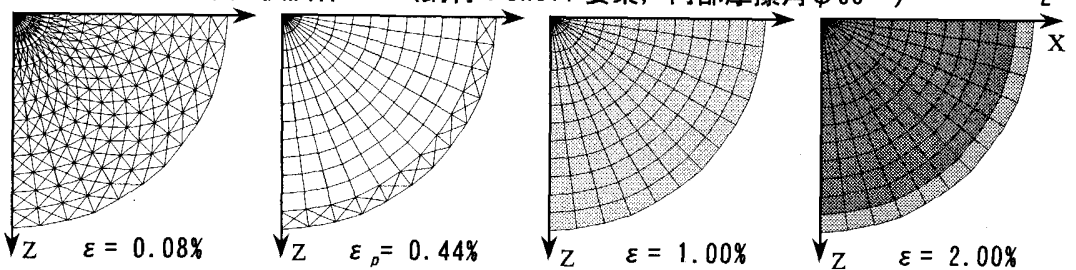

$Z^{2}$ 供試体 $S-2$

（c）供試体 B-2（鋼材：Beam 要素, 内部摩摖角 $\phi 53^{\circ}$ ）1）
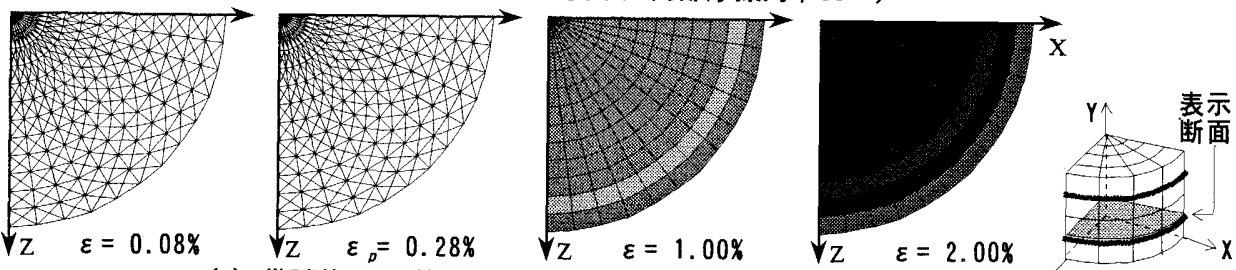

（d）供試体 B-2（鋼材：Beam 要素, 内部摩擦角 $\phi 30^{\circ}$ ）

$Z^{2}$ 供試体 $\mathrm{B}-2$

図-16 供試体 $S-2$ および $B-2$ の横拘束位置 $Y=12.5 \mathrm{~mm}$ での損傷度 $\beta$ の進展図 
ただし，損傷度 $\beta$ の値は異なり，前者（内部摩擦角 $\phi=53^{\circ}$ の場 合）に比較して後者（ $\phi=30^{\circ}$ の場合）の損傷が大きくなっている.

鋼材要素を Beam 要素とした図-16(c)および(d)においても，前 述とほぼ同様な傾向を示しているといえる.すなわち，内部摩擦角 $\phi$ が $53^{\circ}$ から $30^{\circ}$ へと減少しても, 供試体内部における損傷度 $\beta$ の分布状況は顕著には相違しないものの, 損傷度 $\beta$ の絶対值は増大 する傾向を示すことが分かる．ちなみに，供試体内部の応力状態を 調べたところ， $I_{1} / F_{c}$ の值（図-8 参照）は最大でも約 1.5（供試体 S-2）であった，前述の 3.3.2 項の検討結果によれば，内部摩擦角 $\phi$ は比較的大きな值（例えば $53^{\circ}$ ）を設定するのが妥当な応力状 態であると考えられる.

\subsection{4 内部摩擦角 $\phi$ につて}

解析 I および解析 II の検討 結果より, Drucker-Prager 型構 成則を適用する際には, 内部摩 擦角 $\phi$ の值を側圧（または静水 圧）などの応力状態に応じて変 化させることが望ましいと考え られる. 本報で得られた結果を 概念的に示せば，図-17 のよう

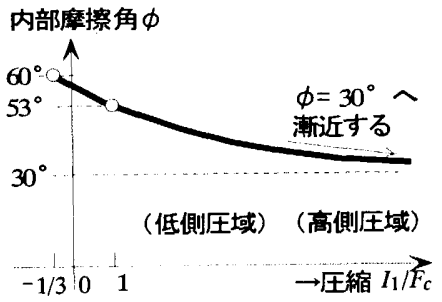

図-17 内部摩擦角 $\phi-I_{1} / F_{c}$ 関係 になる。

\section{5. まとめ}

広範讲の形状比を有する円形プレーンコンクリート供試体および 横拘束方法の異なるコンファインドコンクリートの一軸圧縮 FEM 解析を通して，以下の知見が得られた。

（1）端面摩摖を有する様々な形状のコンクリート供試体の圧縮強度 に対し，Drucker-Prager 型構成則の内部摩擦角を同定した結果， いずれの場合もほほ $30^{\circ}$ 程度であった。

（2）供試体内部に生じる応力状態が低側圧域であれば，内部摩擦角 を高い值（例えば，53）とし，一方，高側圧域では低い值 （例えば， $30^{\circ} \sim 40^{\circ}$ ） とすることで, 実験結果を比較的精度 良く評価することができる，すなわち，内部摩摖角の值は側圧 の大きさに応じて変化させることが望ましいと考えられる.

(3) 帯状および線状に横拘束をうけるコンファインドコンクリート 供試体の X-Y 面（垂直断面）の等価拘束圧の分布によれば，拘 束位置だけではなく，その近傍に位置するガウス積分点での值 も高くなる。

(4) 帯状および線状に横拘束を受けるコンファインドコンクリート 供試体の水平断面内の損傷度の分布によれば，内部摩摖角 $\phi$ の 減少 $\left(53^{\circ} \rightarrow 30^{\circ}\right)$ に伴い, 供試体内部にお汀る損傷度の分布 状況は顕著には相違しないものの, 損傷度の絶対値は増大する 傾向を示す。

謝辞 : 本研究費の一部は, 平成 12-13 年度文部科学省研究费補助金（基 嗌研究 C, 研究代表者 : 畑中重光), 平成 14-15 年度文部科学省研究費 補助金（基盤研究 C, 研究代表者: 水野英二）および平成 14 年度竹中 育英会建築研究助成金（研究代表者：吉田幸夫）によった．記して謝 意を表す.

[引用文献]

1) 吉田幸夫，水野英二，畑中重光 : 境界要素の影響を考虑した円形コンフ アインドコンクリートの任縮破壊 FEM 解析, 日本建築学会構造系論文
集，No.563，pp.169-176，2003. 1

2）吉田幸夫，水野英二，畑中重光 : 円形コンファインドコンクリート内部 の応力と損傷状態に関する三次元 FEM 解析, 日本建築学会学術講演梗 摡集，C-2 構造 IV, pp.167-168，2002.8

3) 吉田幸夫，水野英二，畑中重光 : 異なる形状比を有する円形コンクリー 卜供試体の一軸圧縮 FEM 解析, 日本建築学会東海支部研究報告集, No.42, pp.313-316, 2004.2

4) DIANA Foundation Expertise Center for Computational Mechanics: DIANA Finite Analysis User's Manual, TNO Building and Construction Research., 1999

5) 畑中重光, 服部宏己, 吉田徳雄, 谷川恭雄 : コンファインド高強度コン クリートの圧縮靱性とその評洒, コンクリート構造物の勒性と配筋方法 に関するシンポジウム論文集，pp.1-20，1990.5

6) S. Hatanaka, Y. Kosaka and Y. Tanigawa: Plastic Deformational Behavior of Axially Loaded Concrete under Low Lateral Pressure - An Evaluation Method for Compressive Toughness of Laterally Confined Concretes (Part 1) - Journal of Structural and Construction Engineering, No.377, pp.27-37, July, 1987

7) Zhishen Wu and Tada-aki Tanabe : A Hardening / Softening Model of Concrete Subjected to Compressive Loading, Journal of Structural Engineering, AIJ, 36B, pp.153-162, 1990

8) Hiromichi Yoshikawa and Kazuhiro Yamakawa : Analysis of Inelastic Behavior and Failure Modes of Confined Concrete by Elasto-Plastic Softening Model, Modeling of Inelastic Behavior of RC Structures under Seismic Loads, Edited by P. Benson Shing, Tada-aki Tanabe, ASCE, pp.79-97, 2001

9) A. I. Karabinis and P. D. Kiousis : Effects of Confinement on Concrete Columns: Plasticity Approach, Journal of Strucutal Engineering, Vol. 120, No.9, pp.2747-2767, September, 1994

10) 山川折朗, 張愛堡, 佐藤元 : アラミド織維シートを用いた RC 柱の耐震 補強に関する研究一耐䈔性能に及保す織維補強量および面取り半径の影 響一, 月本建築学会構造系論文集，第 545 号, pp. 111-118, 2001.7

11）中四幸造，山川折朗，森下㫜・，外田尚之：緊張アラミド㵶維ベルトを

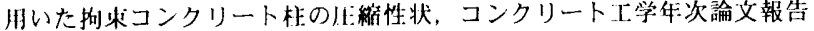
集, Vol.25, No.2, pp.127-132, 2003

12）中川韩造，山川折的，外目尚之：アラミドベルトによりプレストレスを 等入したコンクリート梏の性心綃吽状一その 2 解析一, 日本建築学

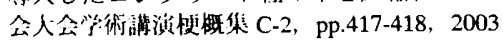

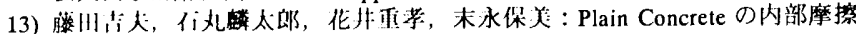

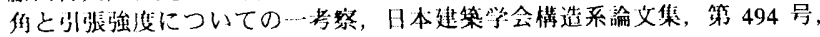
pp. 7-14, 1997. 4

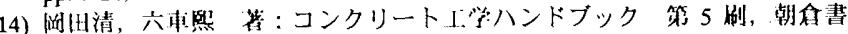
菬, pp.376-377, 1988

15) Drucker, D. C. and W. Prager: Soil Mechanics and Plastic Analysis or Limit Design, Q. Appl. Math., Vol. 10, No. 2, pp.157-165, 1952

16）小阪義夫，谷川热雄，太忖福男：各種の減库材を用いた場合の压綰供試 体端面の応力分布について, コンクリートT学件次講演会講演論文集, Vol. 2, pp.121-124, 1980

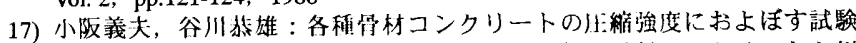

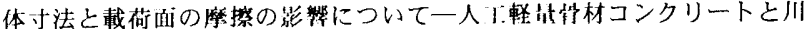
砂・川砂利コンクリートとの比較一，セメント・コンクリート，No. 265 , pp.2-10, 1975.3

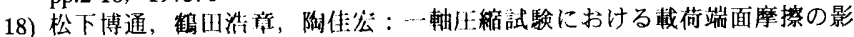
響，セメント・コンクリート論文集，No. 53，pp.621-626, 1999

19) Yoshio Kosaka, Yasuo Tanigawa, Kazuo Yamada and Shigemitsu Hatanaka : Plastic Deformational Behavior of Concrete under Multiaxial Compressive Load, Transaction of JCI, Vol. 5, pp. 169-176, 1983

20) 色部誠, 河角誠, 安達洋 監訳 : コンクリート構造物の塑性解析, 丸善, pp.196-257, 1985

21) 水野英二, 㚼中重光 : コンクリートのひずみ軟化型構成モデルの開発と コンファインドコンクリートの三次元有限要素解析, 土木学会論文集, No.571/V-36, pp.185-197, 1997.8

22）吉田幸夫，水野英二，畑中重光: 円形コンファインドコンクリート内部 の応力と損傷状態に関する FEM 解析, コンクリート工学年次論文報告 集, Vol.24, No.2, pp.97-102, 2002

23）水野英二，森本康介，畑中重光：中心軸圧縮力を受けるコンファインド コンクリートの拘束効果に関する三次元 FEM 解析, コンクリート工学 年次論文報告集, Vol.21, No.3, pp.85-90, 1999

24）辻誠，大工綾子，水野英二，畑中重光：炭素㵶維シートで横補強したコ ンクリートの一軸压縮性状, コンクリート工学年次論文集, Vol.22, No.3, pp.109-114, 2000

25) 中塚佶：コンクリートの応力度一ひずみ度特性とコンクリート曲げ部材 の終茼域特性に関する基礎的研究，大阪大学博士論文，pp.50-52，1988

26）小阪義夫, 谷川恭雄, 畑中重光 : 構成モデルに基づく各種横拘束コンク リートの生縮靱性の統一評価，コンクリート工学年次講演会論文集, Vol.8, pp.365-368, 1986

27) Zienkiewicz, O. C.: The Finite Element Method, Third Ed., （吉識・山田監 訳 : マトリックス有限要素法), 培風館, pp. 672-796, 1984

(2004年 5 月 10 日原稿受理， 2004 年 10 月 4 日採用決定） 